\title{
Morphological Study of Glochidion obovatum under Heavy Browsing Pressure by Sika Deer
}

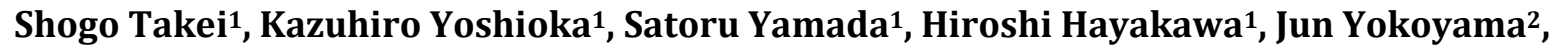 \\ Katsura Ito1, Shinichi Tebayashi', Ryo Arakawa', Tatsuya Fukuda ${ }^{*}$ \\ ${ }^{1}$ Faculty of Agriculture, Kochi University, Kochi, Japan \\ ${ }^{2}$ Faculty of Science, Yamagata University, Yamagata, Japan \\ Email: ${ }^{*}$ tfukuda@kochi-u.ac.jp
}

Received 28 February 2014; revised 28 March 2014; accepted 8 April 2014

Copyright (C) 2014 by authors and Scientific Research Publishing Inc.

This work is licensed under the Creative Commons Attribution International License (CC BY). http://creativecommons.org/licenses/by/4.0/ (c) (i) Open Access

\begin{abstract}
To clarify the modification of physical defences of Glochidion obovatum Sieb. et Zucc., we compared the length of spine-like branches and frequency of lateral branches of $G$. obovatum between Kashima Island, which supports a high density of sika deer (Cervus nippon), and its neighbouring areas. The length of spine-like branches of $G$. obovatum in Kashima Island was not significantly longer than that of the neighbouring areas, but the frequency of lateral branches on the island was higher than that of the neighbouring areas. Since the branches of $G$. obovatum are heavily foraged by the sika deer, the shrub form of the species has evolved into the bonsai form, suggesting increased frequency of occurrence of lateral branches, which could develop as shoot-like branches. Thus, the observed features are facultative defence mechanisms of $G$. obovatum against heavy browsing in a small-sized island with very high density of sika deer.
\end{abstract}

\section{Keywords}

Deer; Defence; Frequency; Herbivore; Island; Sika

\section{Introduction}

Thorns, prickles, spines, and trichomes have often been considered as a defence mechanism against herbivory [1] [2], and plants have developed physical and chemical defences against herbivores. Some studies have reported the stimulation of spine production in Opuntia dillenii (Ker Gawl.) Haw. [3], the increased number of prickles in

${ }^{*}$ Corresponding author. 
Rubus trivialis Michix. [4], R. vestitus Weihe et Nees [5] [6] and Aralia spinosa L. [7], the increased length and number of Zanthoxylum ailanthoides Siebold et Zucc. [8], and the increased trichome density in Urtica thunbergiana Sieb. et Zucc. [9] and Cnidoscolus texanus (Muell. Arg.) Small [10]. Among these, spines would be more effective against vertebrates than invertebrates because of their size relative to the herbivore, and hence vertebrate herbivores should exert a stronger and more consistent selection on leaf spines than invertebrate herbivores [2].

In Japan, comparative studies of physical defence between different browsing pressures by sika deer (Cervus nippon) have been conducted. Kashima Island (32'57"N, 132'27"E; 45.1 ha) is located at the southwestern part of Shikoku, Japan (Figure 1). The island supports a high density of sika deer (ca. 38.5/km²) [11], and therefore, the population of two Rubus species, $R$. sieboldii Blume and $R$. croceacanthus H. Lév., has recently increased in this island [12] [13]. These plant species may have increased physical defence by changing of prickles under the high browsing pressure by sika deer because they have many prickles on leaves and stems, and the differences between individuals in the spinescence induced by browsing sika deer indicate phenotypic variation. Hashigoe (1995) [14] described some plants without many prickles on a leaf and stem in the flora of Kashima Island. How have these been adapted for Kashima Island?

Glochidion obovatum Sieb. et Zucc. (Euphorbiaceae) is a deciduous or subdeciduous shrub with numerous branched branches. Short branches in the apical parts are often spine-like. The plant height of this species is within the range of $1-6 \mathrm{~m}$. The species is endemic to Japan (Honshu [westward from Kinki], Shikoku, Kyushu, and Ryukyu [15] (Figure 2(a)). The habitat of this species is grasslands or open forests of hillside near seashore. This species is also described in the Flora of Kashima Island [14] and we could find them on the edge of forest in this island. G. obovatum has no prickles on its leaves and stems and instead develop spine-like branches [15] (Figure 2(b)). Thus, the spine-like branch of this species is morphologically and embryologically different from the prickles of the Rubus species, which were previously reported by Takei et al. 2013, 2014b [12] [13].

In the shrub form, $G$. obovatum can change to the bonsai type, which is pruned by deer browsing and has shorter and denser branches of less than $1.5 \mathrm{~m}$ in height, or to the compound browsing form, which represents its recovery from the bonsai type to normal type by growing long branches in its pruned surface and is less than 2 $\mathrm{m}$ in height, after being subjected to heavy browsing pressure by sika deer [16]-[19]. In Miyajima Island (34'28"N, 132'31"E), which is located at the Seto Inland Sea, western Japan, this species with a compound browsing form shows a higher frequency of spine-like branches in the lower part (less than $120 \mathrm{~cm}$ in height) than that of in the higher part (more than $120 \mathrm{~cm}$ ) and has a negative correlation between leaf size and spine-like branch frequency caused by the foraging effect of sika deer [16]. In addition, on Nozaki Island (33'21"N, $129 ' 12 " E)$ located at the northwestern part of Kyushu, Japan, this species changed its growth pattern as bonsai type to avoid foraging by sika deer [18]. These reports focused on the growth pattern and interaction between leaf size and spine-like branch frequency by using browsing locations. Morphological analysis of spine-like branch length and comparative analysis of high and low browsing pressures had not been made so far. The events affecting deer browsing is unique for each island because conditions such as the number of sika deer, vegetation, size of island, ecological succession for forest and so on are different. It allows us to understand the modification of physical defence in this species by comparing between Kashima Island (high browsing) and its neighbouring (low browsing) areas. The aim of this study was to clarify the changing pattern of physical defence of G. obovatum to avoid from heavy foraging by sika deer in Kashima Island.

\section{Materials and Methods}

The samples of G. obovatum used in this study were collected from heavy foraging in the island (Kashima Island) and its two neighbouring and not heavily foraged areas (Komo Cape and Ino Cape) in 2012-2013 (Figure 1, Table 1). The individuals of Kashima Island were divided into two categories: more than $1.5 \mathrm{~m}$ high and below $1.5 \mathrm{~m}$. Assuming the browse line, which the boundary between upper normal plant growth and lower stripped and eaten-back growth that indicates the height reached in feeding by sika deer, to be approximately $1.5 \mathrm{~m}$ based on the previous study of Inoue and Kanemori (2006) [20], we analysed the spine-like branches and lateral branches of G. obovatum and compared these among individuals before and behind the browse line. We used the individuals that the plant height was below $1.5 \mathrm{~m}$ in Komo Cape and Ino Cape. To measure the length of spine-like branches of $G$. obovatum, five spine-like branches were collected per individual. We counted all short-lateral branches, which are changeable part as spine-like branches [15], and measured the total branch 


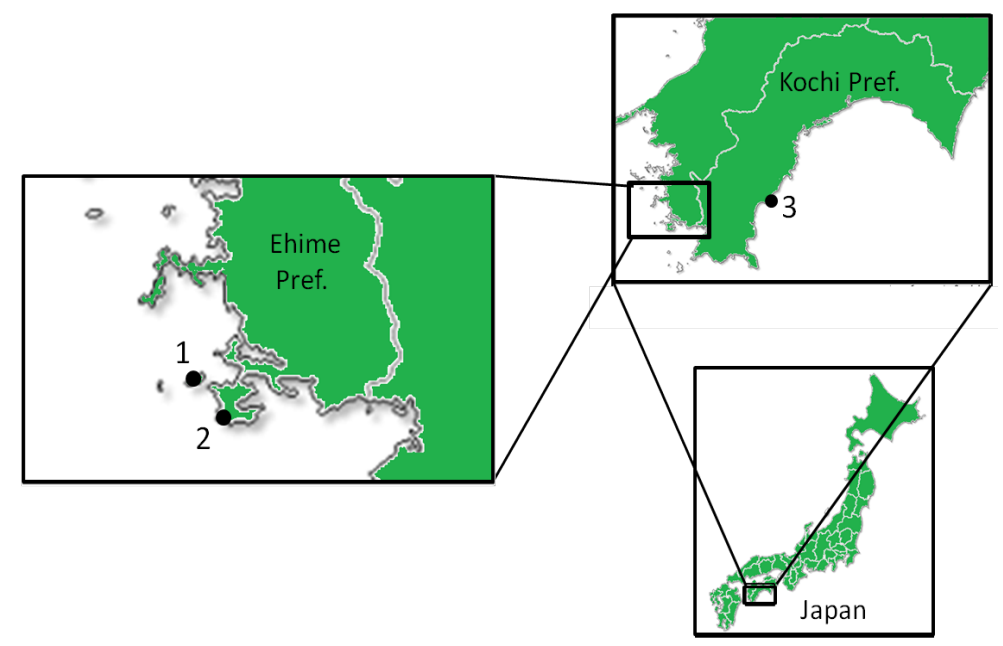

Figure 1. Sampling locations in the study. 1: Kashima Island, 2: Komo Cape, 3: Ino Cape.
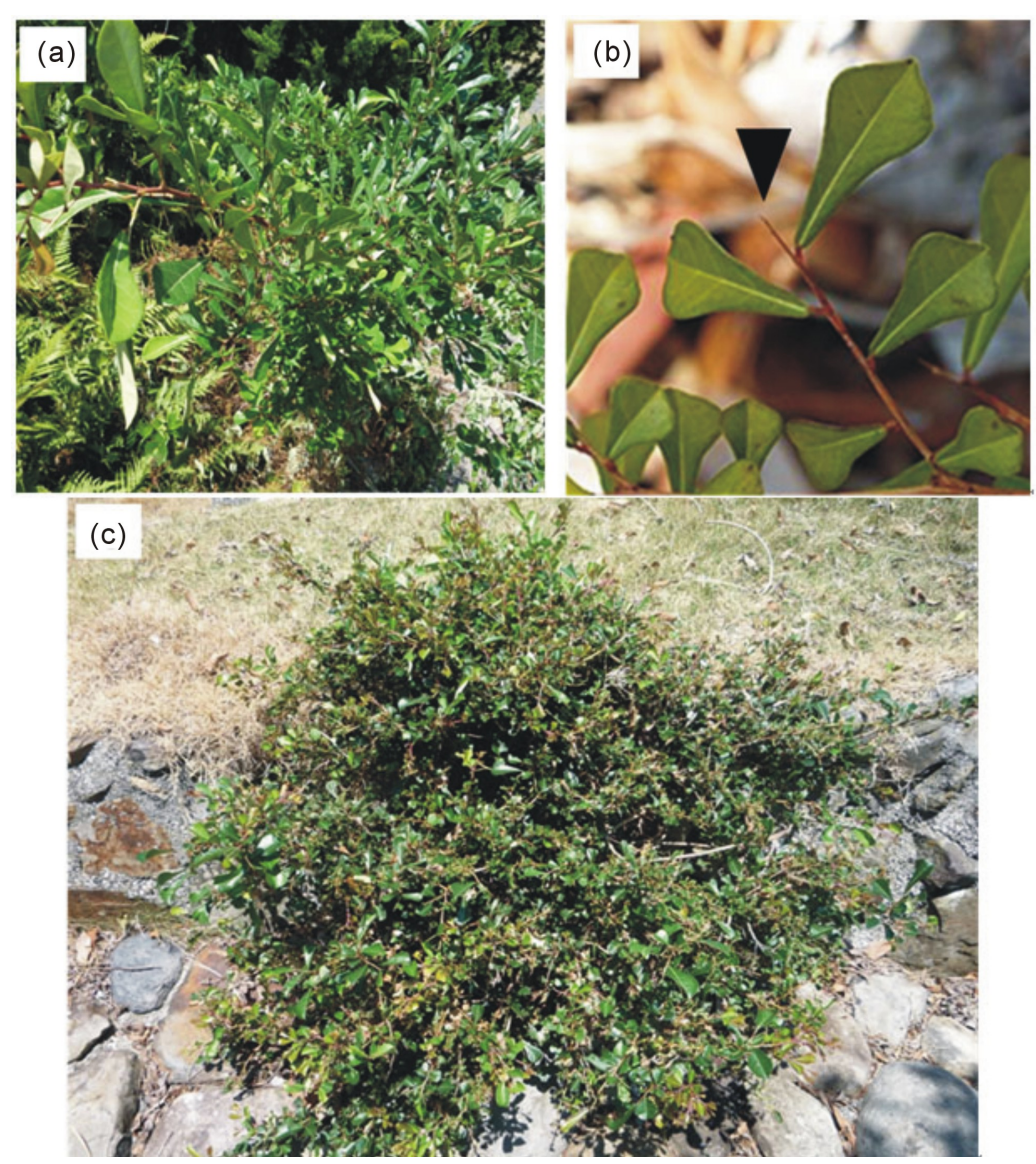

Figure 2. Plant morphology of Glochidion obovatum photographed in Kashima Island. (a) Plant body (>1.5 m); (b) Spine-like branch (>1.5 m); (c) Bonsai type of Glochidion obovatum ( $<1.5 \mathrm{~m})$. Arrowhead indicates a spine-like branch.

length containing less than $30 \mathrm{~cm}$ from the tip of the trunk on each individual. Then, we calculated the lateral branch numbers per secondary branch (all short-lateral branches/sum of branch lengths). All study-specific statistical analyses were performed using SPSS Statistics 19 (IBM SPSS, Chicago, Illinois). 
Table 1. Sampling locations used in this study.

\begin{tabular}{|c|c|c|c|c|}
\hline Location name & Location no. & Number of Individuals & Location & Latitude and longitude \\
\hline Kashima Island (<1.5 m) & 1 & 33 & $\begin{array}{c}\text { Ehime Prefecture, Minamiuwa-Gun, } \\
\text { Ainan-Cho, Kashima }\end{array}$ & $\begin{array}{l}\text { N } 32^{\circ} 56^{\prime} \\
\text { E } 132^{\circ} 27^{\prime}\end{array}$ \\
\hline Kashima Island (>1.5 m) & 1 & 18 & $\begin{array}{c}\text { Ehime Prefecture, Minamiuwa-Gun, } \\
\text { Ainan-Cho, Kashima }\end{array}$ & $\begin{array}{l}\text { N } 32^{\circ} 56^{\prime} \\
\text { E } 132^{\circ} 27^{\prime}\end{array}$ \\
\hline Komo Cape $(<1.5 \mathrm{~m})$ & 2 & 30 & $\begin{array}{c}\text { Ehime Prefecture, Minamiuwa-Gun, } \\
\text { Ainan-Cho, Komo }\end{array}$ & $\begin{array}{l}\mathrm{N} 32^{\circ} 54^{\prime} \\
\mathrm{E} 132^{\circ} 28^{\prime}\end{array}$ \\
\hline Ino Cape $(<1.5 \mathrm{~m})$ & 3 & 17 & $\begin{array}{l}\text { Kochi Prefecture, Hata-Gun, } \\
\text { Kuroshio-Cho, Ino }\end{array}$ & $\begin{array}{l}\mathrm{N} 33^{\circ} 02^{\prime} \\
\mathrm{E} 133^{\circ} 09^{\prime}\end{array}$ \\
\hline
\end{tabular}

\section{Results and Discussion}

We analysed the length of spine-like branches and number of lateral branches of G. obovatum in Kashima Island and its neighbouring areas (Figure 3, Table 2). For the category of below $1.5 \mathrm{~m}$ in height, the length of spine-like branches of G. obovatum in Kashima Island was not significantly longer than those of the other areas (Figure 3, Table 2), suggesting that it does not need to increase the length of its spine-like branches to prevent grazing pressure of sika deer in Kashima Island. On the other hand, the number of lateral branches and number of lateral branches per secondary branch of $G$. obovatum were higher than those of the neighbouring areas (Figure 3, Table 2). Thus, G. obovatum in Kashima Island had a higher frequency of lateral branches on secondary branches.

Why did G. obovatum differ in the number of lateral branches between Kashima Island and its neighbouring areas? One of the answers is that the rise of the number of lateral branch leads to increases in spine-like branches. G. obovatum, under the higher browsing pressure of sika deer, was more changeable from the apical part of the lateral branch to the spine-like branches compared to the weaker browsing pressure [16]. The shoot apexes prevent the growth of lateral buds, which is a phenomenon called apical dominance. However, in apical dominance, after the shoot apex is browsed by vertebrate herbivores and/or damaged by abiotic factors, its lateral buds continuously develop. Therefore, by continuous browsing pressure, the branches of this species were pruned, thus, generating a large number of new lateral branches, resulting in the frequency of lateral branches that further enhances its growth. Therefore, we hypothesized that the lateral branches of G. obovatum are trimmed and pruned by sika deer and consequently this species in Kashima Island have become "bonsai" in form. The bonsai type could have more spine-like shoots than the normal of G. obovatum, and we considered that this species increased its physical defence against high browsing pressure by sika deer to adapt to Kashima Island.

Could we find such bonsai-type plants in other heavily browsed areas by sika deer? Kinkazan Island is a small island (32'57"N, 132'27"E; 959 ha), located on the Pacific side of the (northeastern) Tohoku District, Japan, has a high density of sika deer (ca. 50/ $\mathrm{km}^{2}$ ) [21] and with plants that develop prickles, spines, or thorns: i.e. Cirsium amplexifolium (Nakai) Kitam. var. muraii (Kitam.) Kitam. (Asteraceae). Takatsuki and Ito (2009) [22] reported that the bonsai type of Berberis thunbergii DC. (Berberidaceae) grows abundantly in open lands, particularly in grassland communities of Kinkazan Island. B. thunbergii has spiny around stems [23], and the physical defence of this species could increase by being the bonsai type in Kinkazan Island. In addition, in Nozaki Island, there is the bonsai type of Elaeagnus pungens Thunb. (Elaeagnaceae) with spines adding G. obovatum and which would be caused by heavy browsing of sika deer [17] [24]. Considering these results and our results, changing tree architecture into the bonsai type with spines would be one of common strategies to increase physical defence under high browsing pressure by sika deer.

It is thus possible that $G$. obovatum in Kashima Island shows the bonsai type in order to be reached by browsing sika deer. As the browse line in feeding by sika deer is approximately $1.5 \mathrm{~m}$ [20], we compared the length and number of spine-like branches between individuals of $G$. obovatum before (below $1.5 \mathrm{~m}$ ) and behind (over $1.5 \mathrm{~m}$ ) the browse line in Kashima Island. A significant decrease in the length of spine-like branches over the browse line was observed (Figure 3, Table 2). In fact, for example, some African Acacia species (Fabaceae) have produced long spines on its branches after the tip is browsed, whereas unbrowsed twigs have shorter spines [25]-[27], indicating that the growth pattern of these species would change before and behind the browse line. In addition, the length of spine-like branch, the number of lateral branches of $G$. obovatum significantly decreased 

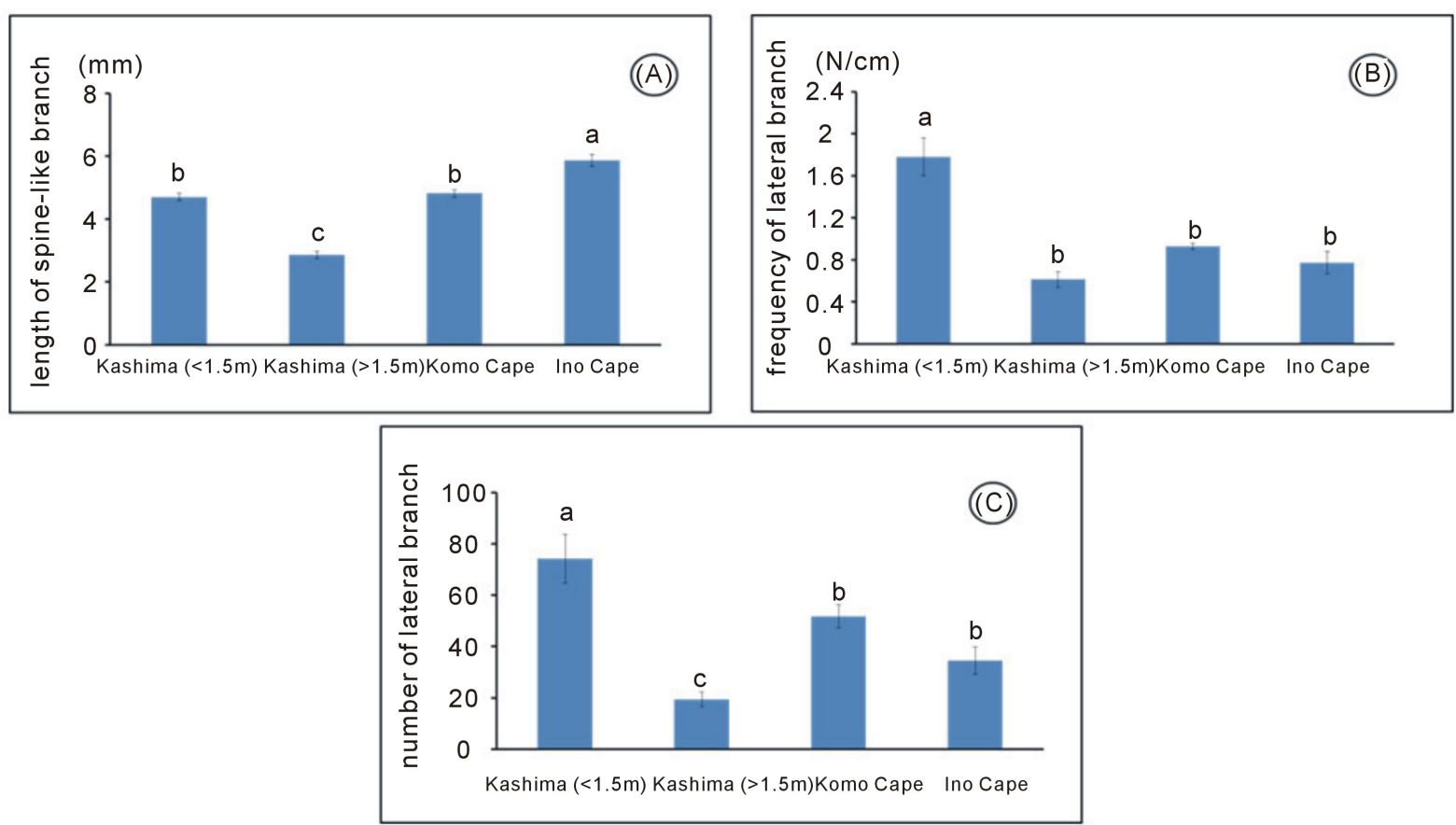

Figure 3. Morphological measurements of Glochidion obovatum. (A) Length of spine-like branch; (B) Frequency of lateral branch; (C) Number of lateral branch.

Table 2. Morphological measurements (mean \pm standard deviation) of Glochidion obovatum.

\begin{tabular}{|c|c|c|c|c|}
\hline Location & $\begin{array}{l}\text { Kashima Island } \\
\qquad(<1.5 \mathrm{~m})\end{array}$ & $\begin{array}{l}\text { Kashima Island } \\
\qquad(>1.5 \mathrm{~m})\end{array}$ & $\begin{array}{l}\text { Komo Cape } \\
(<1.5 \mathrm{~m})\end{array}$ & $\begin{array}{l}\text { Ino Cape } \\
(<1.5 \mathrm{~m})\end{array}$ \\
\hline Length of spine-like branch (mm) & $4.69 \pm 0.12^{b}$ & $2.85 \pm 0.12^{c}$ & $4.81 \pm 0.13^{\mathrm{b}}$ & $5.86 \pm 0.20^{\mathrm{a}}$ \\
\hline Frequency of lateral branch (N/cm) & $1.78 \pm 0.18^{\mathrm{a}}$ & $0.61 \pm 0.08^{\mathrm{b}}$ & $0.92 \pm 0.03^{\mathrm{b}}$ & $0.77 \pm 0.11^{\mathrm{b}}$ \\
\hline Number of lateral branch (N) & $74.12 \pm 9.58^{\mathrm{a}}$ & $19.35 \pm 2.72^{c}$ & $51.76 \pm 4.59^{\mathrm{b}}$ & $34.45 \pm 5.25^{b}$ \\
\hline
\end{tabular}

beyond the browse line (Figure 3, Table 2). Thus, the upper part of individuals of G. obovatum in Kashima Island could be released from heavy browsing pressure and became the normal growth pattern when its height exceeds the browse line, resulting in the transformation of the shrub form of G. obovatum into a compound browsed form from bonsai type. Okuda (1987) [16] indicated that G. obovatum individuals with compound browsed form resulted from facultative defence mechanism. Therefore, changing of the growth pattern of $G$. obovatum in Kashima Island from the bonsai to the compound browsed form may be not special but a general phenomenon such as the previous reports of Miyajima Island [16] and Nozaki Island [17].

\section{Acknowledgements}

We wish to thank Mr. Moriguchi Y. for providing useful comments of Kashima Island and Drs. Ohga K., Miyata H., Tsuchiya Y., Yoshimi Y., Muroi M., Isomoto S., Matsuyama K., Yokoyama N., Sunami T., Kumekawa Y., Kakimoto N., Matsui R., Inoue S., Uemoto C., Ozaki Y., Orito M., Kuribayashi S., Suzaki S., Fujiwara K., Minato Y., Miyake K. and Yamamoto F. for providing us with much-needed assistance. This study was partly supported by Grant-in-Aid for Scientific Research from the Ministry of Education, Science and Culture of Japan (to TF and JY).

\section{References}

[1] Ehrlich, P.R. and Raven, P.H. (1967) Butterflies and Plants. Scientific American, 216, 104-131. http://dx.doi.org/10.1038/scientificamerican0667-104

[2] Grubb, P.J. (1992) A Positive Distrust in Simplicity: Lessons from Plant Defenses and from Competition among Plants 
and among Animals. Journal of Ecology, 80, 585-610. http://dx.doi.org/10.2307/2260852

[3] Myers, J.H. (1987) Nutrient Availability and the Deployment of Mechanical Defenses in Grazed Plants: A New Experimental Approach to the Optimal Defense Theory. Oikos, 49, 350-351. http://dx.doi.org/10.2307/3565772

[4] Abrahamson, W.G. (1975) Reproductive Strategies in Dewberries. Ecology, 56, 721-726. http://dx.doi.org/10.2307/1935508

[5] Bazely, D.R., Myers, J.H. and Burke da Silva, K. (1991) The Response of Number of Bramble Prickles to Herbivory and Depressed Resource Availability. Oikos, 61, 327-336. http://dx.doi.org/10.2307/3545240

[6] Gibson, D., Bazely, D.R. and Shore, J.S. (1993) Responses of Brambles, Rubus vestitus, to Herbivory. Oecologia, 95, 454-457. http://dx.doi.org/10.1007/BF00321002

[7] White, P.S. (1988) Prickle Distribution in Aralia spinosa (Araliaceae). American Journal of Botany, 75, $282-285$. http://dx.doi.org/10.2307/2443895

[8] Takei, S., Yoshioka, K., Yamada, S., Hayakawa, H., Yokoyama, J., Ito, K., Tebayashi, S., Arakawa, R. and Fukuda, T. (2014) The Length and Density of Prickles on Zanthoxylum ailanthoides (Rutaceae): A Comparison of Japanese Islands with Different Sika Deer Browsing Pressures. American Journal of Plant Science, 5, 332-337. http://dx.doi.org/10.4236/ajps.2014.53046

[9] Pullin, A.S. and Gilbert, J.E. (1989) The Stinging Nettle, Urtica dioica, Increases Trichome Density after Herbivore and Mechanical Damage. Oikos, 54, 275-280. http://dx.doi.org/10.2307/3565285

[10] Pollard, J.A. (1986) Variation in Cnidoscolus texanus in Relation to Herbivory. Oecologia, 70, 411-413. http://dx.doi.org/10.1007/BF00379504

[11] Takatsuki, S. (1982) Ecological Studies on Effect of Sika Deer (Cervus Nippon) on Vegetation III: The Vegetation of Iyo-Kashima Island, Southwestern Shikoku, with Reference to Grazing Effect of Sika Deer. Ecological Reviews, 20, $15-29$.

[12] Takei, S., Ohga, K., Hayakawa, H., Yokoyama, J., Ito, K., Tebayashi, S., Arakawa, R. and Fukuda, T. (2013) Comparative Analysis of the Prickles on Rubus sieboldi (Rosaceae) Between Grazed and Ungrazed Areas in South-western Shikoku, Japan. Journal of Plant Studies, 2, 152-157. http://dx.doi.org/10.5539/jps.v2n1p152

[13] Takei, S., Yoshioka, K., Yamada, S., Hayakawa, H., Yokoyama, J., Ito, K., Tebayashi, S., Arakawa, R. and Fukuda, T. (2014) Comparative Morphology of Prickles of Rubus croceacanthus H. Lév. (Rosaceae) in Kashima Island and its Neighbor Areas. Journal of Plant Studies, 3, 96-102. http://dx.doi.org/10.5539/jps.v3n1p96

[14] Hashigoe, S. (1995) Flora of Kashima Island, Ehime Prefecture, Japan. Biology in Southern Ehime, 8, 22-32. (in Japanese)

[15] Ohba, H. (1999) Glochidion J. R. Forest. and G. Forest. In: Iwatsuki, K., Bufford, D.E. and Ohba, H., Eds., Flora of Japan, Volume IIc, Kodansha, Tokyo, 9-11.

[16] Okuda, T. (1987) The Phenotypic Variation of Glochidion obovatum Sieb. Et Zucc. in Relation to the Deer Browsing. Hikobia, 10, 13-19.

[17] Kawahara, H. (1992) The Correlation between Browsing Behaviour by Sika Deer and the Changing of the Flora of Nozaki Island. Bulletin of Nagasaki Institute of Applied Science, 33, 137-144. (in Japanese)

[18] Kawahara, H. (1997) The Influence of the Vegetation in Nozaki Island for Browsing by Sika Deer and the Management of Sika Deer. Bulletin of Nagasaki Institute of Applied Science, 15, 61-67. (in Japanese)

[19] Takatsuki, S. and Saka, K. (1988) Recovery of Viburnum dilatatum after a Die-off of Sika Deer on Kinkazan Island. Ecological Review, 21, 177-181.

[20] Inoue, M. and Kanemori, H. (2006) The Protection of Mountains and Fields from Sika Deer. Noubunkyou, Tokyo. (in Japanese)

[21] Takatsuki, S. (2006) Ecological History of Sika Deer. University of Tokyo Press, Tokyo. (in Japanese)

[22] Takatsuki, S. and Ito, T.Y. (2009) Plants and Plant Communities on Kinkazan Island, Northern Japan, in Relation to Sika Deer Herbivory. In: McCullough, D.R., Takatsuki, S. and Kaji, K., Eds., Sika Deer: Biology and Management of Native and Introduced Populations, Springer, Tokyo, 125-143. http://dx.doi.org/10.1007/978-4-431-09429-6_9

[23] Terabayashi, S. (2006) Berberis L. In: Iwatsuki, K., Bufford, D.E., Ohba, H., Eds., Flora of Japan, Volume IIa, Kodansha, Tokyo, 342-343.

[24] Kawahara, H. (1983) The Vegetation of Goto and Nozaki Islands. Bulletin of Nagasaki Institute of Applied Science, 24, 239-248. (in Japanese)

[25] Seif el Din, A. and Obeid, M. (1971) Ecological Studies of the Vegetation of the Sudan. IV. The Effects of Simulated Grazing on the Growth of Acacia senegal (L.) Willd. Seedlings. Journal of Applied Ecology, 8, 211-216. http://dx.doi.org/10.2307/2402139 
[26] Young, T.P. (1987) Increased Thorn Length in Acacia depranolobium: An Induced Response to Browsing. Oecologia, 71, 436-438. http://dx.doi.org/10.1007/BF00378718

[27] Milewski, A.V., Young, T.P. and Madden, D. (1991) Thorns as Induced Defenses: Experimental Evidence. Oecologia, 86, 70-75. http://dx.doi.org/10.1007/BF00317391 